\title{
Diagnosis and treatment of iron deficiency anemia during pregnancy and the postpartum period: Iron deficiency anemia working group consensus report
}

\author{
Gebelikte ve postpartum dönemde demir eksikliği anemisi tanı ve \\ tedavisi: Demir eksikliği anemisi çalışma grubu ortak görüş raporu
}

\author{
Olus Api ${ }^{1}$, Christian Breyman ${ }^{2}$, Mustafa Çetiner ${ }^{3}$, Cansun Demir ${ }^{4}$, Tevfik Ecder ${ }^{5}$ \\ 1 Yeditepe University Hospital, Clinic of Gynecology and Obstetrics, İstanbul, Turkey \\ 2Zurich University Hospital, Feto Maternal Hematology Unit, Zurich, Switzerland \\ ${ }^{3}$ Koç University Faculty of Medicine American Hospital, Department of Hematology, İstanbul, Turkey \\ ${ }^{4}$ Çukurova University Faculty of Medicine, Department of Gynecology and Obstetrics, Adana, Turkey \\ 5İstanbul Bilim University Faculty of Medicine, Department of Internal Medicine, Division of Nephrology, İstanbul, Turkey
}

\begin{abstract}
According to the World Health Organization (WHO), anemia is the most common disease, affecting >1.5 billion people worldwide. Furthermore, iron deficiency anemia (IDA) accounts for $50 \%$ of cases of anemia. IDA is common during pregnancy and the postpartum period, and can lead to serious maternal and fetal complications. The aim of this report was to present the experiences of a multidisciplinary expert group, and to establish reference guidelines for the optimal diagnosis and treatment of IDA during pregnancy and the postpartum period. Studies and guidelines on the diagnosis and treatment of IDA published in Turkish and international journals were reviewed. Conclusive recommendations were made by an expert panel aiming for a scientific consensus. Measurement of serum ferritin has the highest sensitivity and specificity for diagnosis of IDA unless there is a concurrent inflammatory condition. The lower threshold value for hemoglobin $(\mathrm{Hb})$ in pregnant women is $<11 \mathrm{~g} / \mathrm{dL}$ during the $1^{\text {st }}$ and $3^{\text {rd }}$ trimesters, and $<10.5 \mathrm{~g} / \mathrm{dL}$ during the $2^{\text {nd }}$ trimester. In postpartum period a $\mathrm{Hb}$ concentration $<10 \mathrm{~g} / \mathrm{dL}$ indicates clinically significant anemia. Oral iron therapy is given as the first-line treatment for IDA. Although current data are limited, intravenous (IV) iron therapy is an alternative therapeutic option in patients who do not respond to oral iron therapy, have adverse reactions, do not comply with oral iron treatment, have a very low Hb concentration, and require rapid iron repletion. IV iron preparations can be safely used for the treatment of IDA during pregnancy and the postpartum period, and are more beneficial than oral iron preparations in specific indications.
\end{abstract}

Keywords: Iron deficiency anemia, pregnancy, postpartum period, intravenous iron therapy

$\ddot{\mathrm{O} z}$

Amaç: Dünya Sağlık Örgütü’nün (DSÖ) araştırmasına göre anemi tüm dünyada 1,5 milyardan fazla kişiyi etkileyen en yaygın hastalıktır. Tüm dünyadaki anemi oranının yarısını demir eksikliği anemisi (DEA) oluşturmaktadır. Gebelikte ve postpartum dönemde DEA sık görülür ve ciddi maternal ve fetal komplikasyonlara yol açabilir. Bu çalışmanın amacı, bir multidisipliner uzman grubunun deneyimlerini paylaşmak ve gebelikteki ve postpartum dönemdeki demir eksikliği anemisine dair optimal tanı ve tedavi yaklaşımları için bir referans oluşturmaktır. DEA tanı ve tedavisi ile ilgili ulusal ve uluslararası dergilerde yayınlanmış çalıșmalar ve kılavuzlar gözden geçirildi. Uzman paneli tarafından konsensus yöntemi kullanılarak sonuç mahiyetinde öneriler oluşturuldu. Eş zamanlı inflamatuvar bir durum olmadıkça, DEA tanısı için en yüksek duyarlılığa ve özgüllüğe sahip test serum ferritin ölçümüdür. Gebelikte en düşük hemoglobin (Hb) eşik değeri 1. ve 3. trimester boyunca <1l gr/dL, 2. trimester boyunca $<10,5$ gr/dL'dir. Postpartum dönemde Hb değerinin $10 \mathrm{gr} / \mathrm{dL}$ 'nin altına inmesi ciddi anemiye işaret eder. Oral demir tedavisi DEA'da birinci basamak tedavi olarak verilir. Her ne kadar veriler şimdilik sınırlı olsa da; oral tedavi yanıtsızlığı, yan etkilerin varlı̆̆ı, tedaviye uyum sorunu, çok düşük hemoglobin değerleri ve hızlı demir replasmanına ihtiyaç duyulması gibi durumlarda intravenöz (IV) demir tedavisi tercih edilebilecek bir alternatiftir. Gebelikte ve postpartum dönemde görülen DEA tedavisinde IV demir preparatları güvenle kullanılabilirler ve bazı spesifik endikasyonlarda oral preparatlardan daha yararlıdırlar.

Anahtar Kelimeler: Demir eksikliği anemisi, gebelik, postpartum dönem, intravenöz demir tedavisi 


\section{Introduction}

According to the World Health Organization (WHO), anemia affects approximately 1.5 billion people worldwide. The prevalence is very high in Africa, Asia, India, Latin America, Eastern Europe, and China; however, it is also high in developed countries $(1,2)$.

Anemia has the highest prevalence in 3 groups: children aged $<5$ years $(47 \%)$, pregnant women $(42 \%)$, and women of reproductive age (30\%). Iron deficiency is seen in $50 \%$ of cases and is the most common cause of anemia(1,2). No national epidemiologic study on the prevalence of anemia has been conducted in Turkey but some regional studies have been performed(3-10). The WHO placed Turkey on the worldwide anemia map by extrapolating these data. Accordingly, Turkey is in the intermediate group, with a prevalence of anemia between $20 \%$ and $39.9 \%$ among women of reproductive age, and is in the severe group for pregnant women, with a prevalence of $40 \%(1,2)$.

Attention has focused on the alternative use of intravenous (IV) iron preparations because oral iron therapy has some disadvantages(11-13). Many studies on IV iron sucrose and ferric carboxymaltose have been conducted. Data on other IV iron preparations such as iron gluconate, iron sorbitol, iron polymaltose, iron isomaltoside, and low molecular weight iron dextran are very limited, and there are increasing safety concerns about high molecular weight iron dextran, which is no longer available in Europe due to a high rate of serious adverse events.

Recent guidelines published in England, Switzerland, Germany, and Asia-Pacific have included IV iron therapy, and the Network for Advancement of Transfusion Alternatives (NATA) also published reports on the indications for IV iron therapy(14-18).

Recommendations

- Large-scale, multicenter studies should be performed to accurately collect population-based data on iron deficiency anemia in Turkey.

\section{Materials and Methods}

The members of the working group reviewed the studies and guidelines on the diagnosis and treatment of iron deficiency anemia published in Turkish and international journals. About 200 literature articles were screened. Search terms were iron deficiency anemia, pregnancy, postpartum period, and parenteral iron therapy. Sources about iron deficiency prophylaxis and oral iron therapy were excluded because the focus was iron deficiency anemia and parenteral iron therapy. The included sources were listed in references part. With the data from the reviewed literature and the working group's own experiences, conclusive recommendations were made as a scientific consensus.
What follows is a review of the diagnosis of iron deficiency anemia and intravenous iron therapy; prophylaxis and oral iron therapy will not be discussed.

\section{Iron deficiency anemia during pregnancy}

\section{Diagnosis}

The major signs and symptoms of iron deficiency anemia can be summarized as fatigue, low physical and mental capacity, headache, vertigo, leg cramps, pagophagia, cold intolerance, koilonychias, mucosal paleness, and angular stomatitis. Iron deficiency anemia during pregnancy poses a number of maternal and fetal problems, including premature birth, intrauterine developmental retardation, placental problems, a decrease in newborn iron storage, the risk of a decrease in maternal blood reserves during birth, and the need for transfusion in cases of heavy blood loss, cardiac stress, symptoms of anemia, prolonged hospital stay, decreased maternal breast milk production, and maternal depletion of iron stores during and after the postpartum period. As such, diagnosis and effective treatment of iron deficiency anemia are of critical importance(19-22).

The most important factor in the diagnosis of iron deficiency anemia is laboratory testing. The classic laboratory findings of iron deficiency anemia include a decrease in the hemoglobin $(\mathrm{Hb})$ level, serum iron concentration, serum transferrin saturation, and serum ferritin level, and an increase in total ironbinding capacity. In fact, it is adequate to study the complete blood count and serum ferritin for diagnosis. A serum ferritin concentration $<30 \mu \mathrm{g} / \mathrm{L}$ together with an $\mathrm{Hb}$ concentration $<11 \mathrm{~g} / \mathrm{dL}$ during the $1^{\text {st }}$ trimester, $<10.5 \mathrm{~g} / \mathrm{dL}$ during the $2^{\text {nd }}$ trimester, and $<11 \mathrm{~g} / \mathrm{dL}$ during the 3 rd trimester are diagnostic for anemia during pregnancy. Measurement of the serum ferritin concentration is the most accurate test in patients without underlying inflammation, and a serum ferritin level below the threshold value alone is adequate for diagnosis in the absence of other tests; however, physicians should be aware that serum ferritin is also an acute phase reactant and may be normal, even elevated, under inflammatory conditions despite the presence of anemia, and in such cases confirmation of the diagnosis may require additional tests.

It is recommended to measure serum ferritin at least once early in pregnancy. If ferritin and hemoglobin indicate iron deficiency anemia, anemia treatment should be initiated (note that intravenous iron is not warranted for the use in first trimester); if ferritin and hemoglobin levels are normal, prophylactic oral iron therapy should be commenced. It is not necessary to measure serum ferritin again later in pregnancy unless the symptoms of anemia occur. On the other hand, $\mathrm{Hb}$ should be measured in each trimester because the probability of an increase in the need for iron and development of iron deficiency is always possible, even if the baseline value is normal. Moreover, the $\mathrm{Hb}$ concentration during delivery is important because a low maternal $\mathrm{Hb}$ can result in fetal problems, including mortality $(1,17,23-27)$. 
If serum ferritin is low $(<30 \mu \mathrm{g} / \mathrm{L})$, but the $\mathrm{Hb}$ is normal $\left(\geq 11 \mathrm{~g} / \mathrm{dL}\right.$ during the $1^{\text {st }}$ trimester, $\geq 10.5 \mathrm{~g} / \mathrm{dL}$ during the $2^{\text {nd }}$ trimester, and $\geq 11 \mathrm{~g} / \mathrm{dL}$ during the 3 rd trimester) the diagnosis is iron deficiency; however, if serum ferritin is low $(<30 \mu \mathrm{g} / \mathrm{L})$ and $\mathrm{Hb}$ is also low $\left(<11 \mathrm{~g} / \mathrm{dL}\right.$ during the $1^{\text {st }}$ trimester, $<10.5$ $\mathrm{g} / \mathrm{dL}$ during the $2^{\text {nd }}$ trimester, and $<11 \mathrm{~g} / \mathrm{dL}$ during the $3^{\text {rd }}$ trimester), the diagnosis is iron deficiency anemia. When $\mathrm{Hb}$ is low $\left(<11 \mathrm{~g} / \mathrm{dL}\right.$ during the $1^{\text {st }}$ trimester, $<10.5 \mathrm{~g} / \mathrm{dL}$ during the $2^{\text {nd }}$ trimester, and $<11 \mathrm{~g} / \mathrm{dL}$ during the $3^{\text {rd }}$ trimester), but serum ferritin is normal $(\geq 30 \mu \mathrm{g} / \mathrm{L})$ additional tests, such as transferrin saturation, serum iron, total iron-binding capacity, and C-reactive protein (CRP), are needed for diagnosis. When serum ferritin is normal $(\geq 30 \mu \mathrm{g} / \mathrm{L})$, but mean corpuscular volume (MCV) is low ( $<70 \mathrm{fL}$ ) in the absence of inflammation, the diagnosis might be thalassemia and further investigation is required (Figure 1).

\section{Recommendations}

- The serum ferritin level, which is the most sensitive test at baseline, should be measured together with the $\mathrm{Hb}$ level to diagnose iron deficiency. A serum ferritin level $<30 \mu \mathrm{g} / \mathrm{L}$ during pregnancy should prompt treatment. Monitoring in further periods should be based on the Hb concentration, which should be measured in each trimester.

\section{Treatment}

As the need for iron increases during pregnancy, prophylactic oral iron therapy is given to all pregnant women with normal laboratory values; however, the primary cause of morbidity is iron deficiency anemia. Data suggesting that anemia causes cardiovascular diseases in further stages of life are increasing. Oral iron preparations can be used throughout pregnancy, whereas IV iron therapy is recommended during the $2^{\text {nd }}$ and $3^{\text {rd }}$ trimesters. There are some instances for which switching to an IV iron preparation is advantageous (Table 1). Actually, IV iron therapy should be the first option in the presence of severe anemia and risk factors, and in emergency situations, because IV therapy is more effective and rapid than oral therapy for resolving anemia( $(1,17,26,28-30)$.

Threshold values for $\mathrm{Hb}$ that indicate oral or IV iron therapy during pregnancy according to countries and guidelines:

$\begin{array}{lll}\text { Pregnancy } & \text { Oral iron } & \text { IV iron } \\ \text { Switzerland } & 9<\mathrm{Hb} \leq 10.5 \mathrm{~g} / \mathrm{dL} & \mathrm{Hb} \leq 9 \mathrm{~g} / \mathrm{dL} \\ \text { Germany } & 9<\mathrm{Hb} \leq 11.5 \mathrm{~g} / \mathrm{dL} & \mathrm{Hb} \leq 9 \mathrm{~g} / \mathrm{dL} \\ \text { Asia-Pacific } & 10<\mathrm{Hb} \leq 10.5 \mathrm{~g} / \mathrm{dL} & \mathrm{Hb} \leq 10 \mathrm{~g} / \mathrm{dL} \\ \text { NATA } & \begin{array}{l}\mathrm{Hb} \leq 11 \mathrm{~g} / \mathrm{dL}(2 \mathrm{nd} \\ \text { Trimester })\end{array} & \mathrm{Hb} \leq 11 \mathrm{~g} / \mathrm{dL}(3 \mathrm{rd} \\ & \text { Trimester })\end{array}$

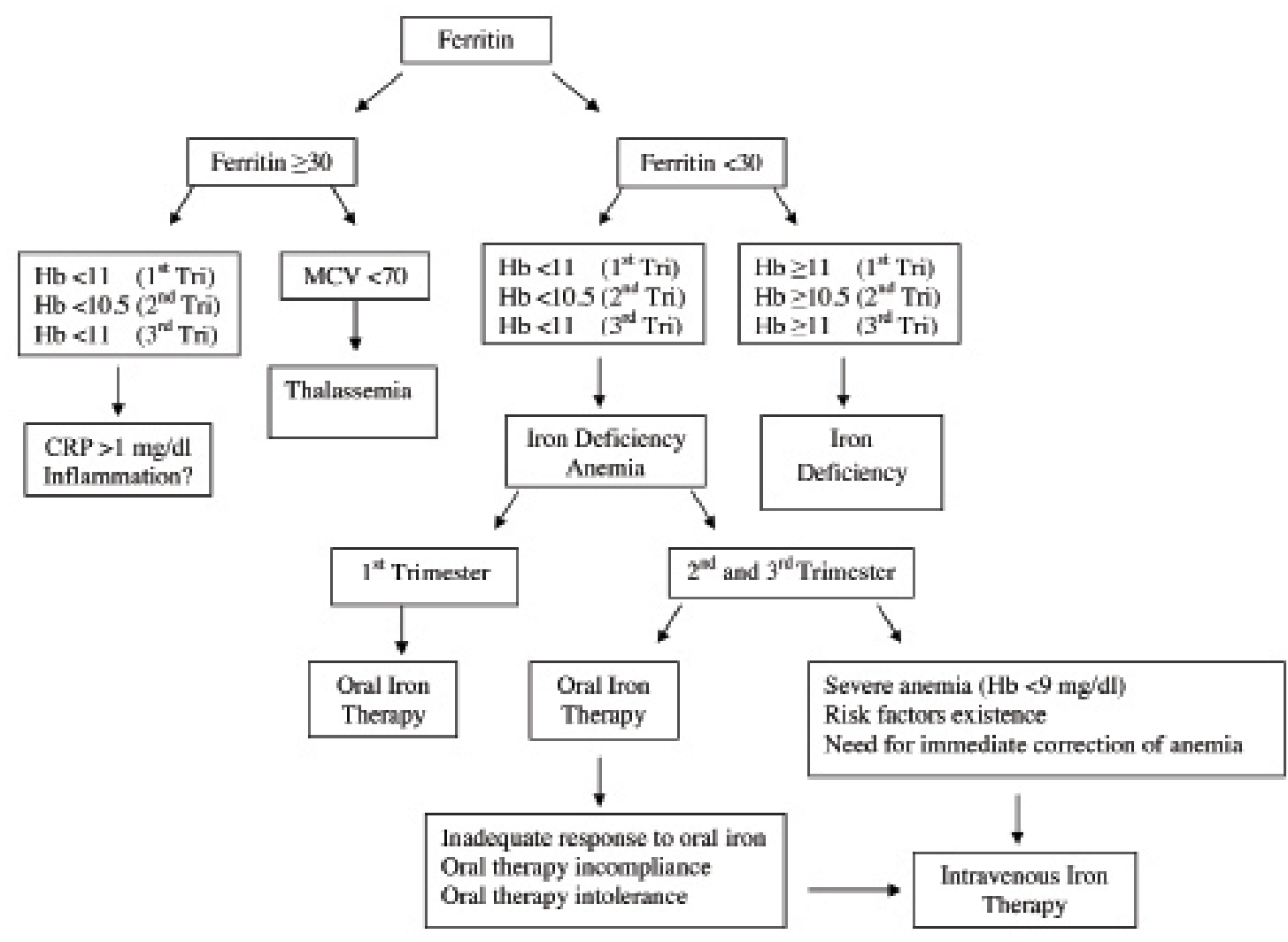

Figure 1. Algorithm for the diagnosis and treatment of iron deficiency anemia during pregnancy 
$\mathrm{Hb}$ threshold values can be higher in the presence of additional risk factors, such as coagulation disorders and placenta previa. The reason that $\mathrm{Hb}$ threshold levels are higher in Asia-Pacific countries is that there the goal of reducing the need for blood transfusion is achieved via IV iron therapy because blood transfusion cannot be performed frequently(14-18).

\section{Recommendations}

- IV iron therapy should be considered from the $2^{\text {nd }}$ trimester onwards in pregnant women with iron deficiency anemia that cannot tolerate or do not respond to oral iron therapy.

- With severe anemia ( $\mathrm{Hb} \leq 9 \mathrm{~g} / \mathrm{dL}$ ), the presence of risk factors (such as coagulation disorders, placenta previa) and conditions that require prompt resolution of anemia (paleness, tachycardia, tachypnea, syncope, heart failure, respiratory failure, angina pectoris, and signs of cerebral hypoxia) are other potential indications for IV iron therapy.

- The IV iron therapy dose should be individual patient based and bringing the $\mathrm{Hb}$ level up to at least $11 \mathrm{~g} / \mathrm{dL}$ should be the target of the therapy.

- Switching from oral to IV iron therapy or starting IV therapy initially is contingent upon risk-benefit assessment; however, such assessment should be performed on an individual patient basis and requirements should be evaluated carefully.

$\begin{array}{lll}\text { Pregnancy } & \text { Oral iron } & \text { IV iron } \\ \text { Turkey } & \left.9<\mathrm{Hb} \leq 11 \mathrm{~g} / \mathrm{dL} \text { (1 }{ }^{\text {st }} \text { and } 3 \text { rd trimester }\right) & \mathrm{Hb} \leq 9 \mathrm{~g} / \mathrm{dL} \\ & 9<\mathrm{Hb} \leq 10.5 \mathrm{~g} / \mathrm{dL} \text { (2nd trimester) } & \end{array}$

\section{Iron deficiency anemia during the postpartum period}

\section{Diagnosis}

Postpartum anemia occurs primarily due to inadequate iron intake before and during pregnancy, and blood loss during delivery. In other words, the combination of iron deficiency anemia and hemorrhagic anemia leads to postpartum anemia. Postpartum anemia has been associated with depression, stress, anxiety, cognitive impairment, decreased mother-infant attachment, and infant developmental retardation. The $\mathrm{Hb}$ concentration must be checked in patients with excessive blood loss during delivery and/ or in those with puerperal symptoms of anemia. A postpartum $\mathrm{Hb}$ concentration $\leq 10 \mathrm{~g} / \mathrm{dL}$ indicates clinically significant anemia. Moderate-to-severe anemia is considered when $\mathrm{Hb}$ is between 9-10 $\mathrm{g} / \mathrm{dL}$ and an $\mathrm{Hb}$ concentration $\leq 9 \mathrm{~g} / \mathrm{dL}$ is considered severe anemia $(17,18,27,31-34)$. It is not meaningful to measure the serum level of ferritin, an acute phase reactant, because it can be normal or elevated during the first 6 weeks post delivery (Figure 2).

Recommendations

- The $\mathrm{Hb}$ concentration must be checked within 24-48 h after delivery in cases of blood loss $>500 \mathrm{~mL}$ during the postpartum period, untreated anemia during the antenatal period, or symptoms of anemia during the postnatal period.

\section{Treatment}

Treatment is based on the severity of anemia and health status of the puerperal. As a rule, oral iron therapy is recommended

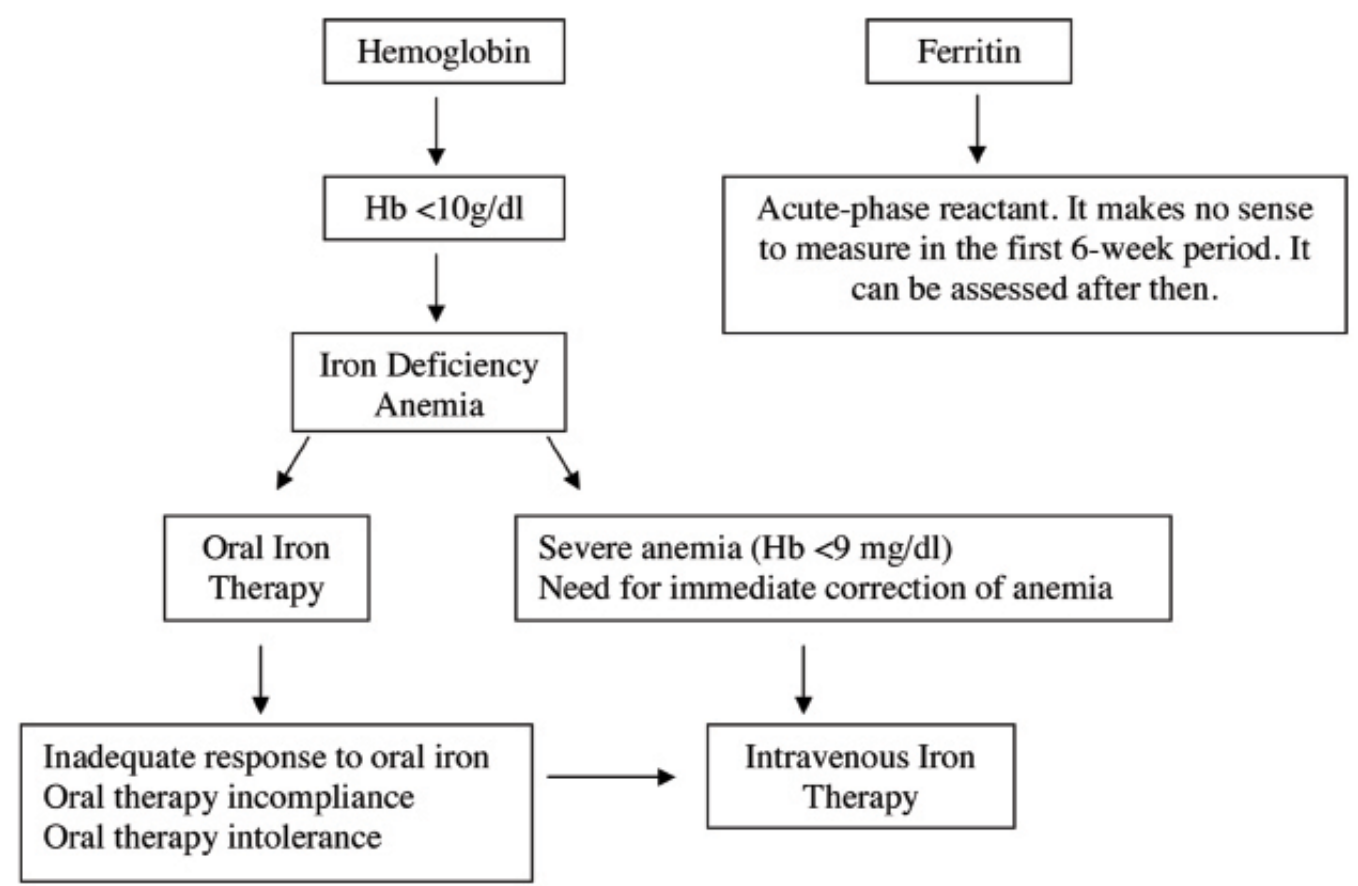

Figure 2. Algorithm for the diagnosis and treatment of iron deficiency anemia during the postpartum period 
in cases of mild anemia; however, it can be switched to IV iron therapy in patients with moderate and severe anemia or in those who cannot tolerate oral iron therapy. After achieving the target values, maintenance therapy can be administered using oral iron preparations. Many studies have reported that IV iron administration is more advantageous than oral administration(12,13,17,35-37). Heavy blood loss can occur in women who begin delivery while anemic, and blood transfusion becomes necessary when the Hb concentration drops to $7 \mathrm{~g} / \mathrm{dL}$. One study reported that $18 \%$ of women who were hospitalized for anemia and postpartum bleeding received transfusion. Another advantage of IV iron therapy is that it reduces the need for blood transfusion. Blood transfusion is in essence a type of transplantation and is associated with serious safety risks, high costs, and availability issues. Transfusion-induced sensitization is another risk for the future. Additionally, IV iron therapy is associated with a shorter duration of hospitalization(38-42). Various $\mathrm{Hb}$ threshold values that indicate oral iron and IV iron therapy during the postpartum period:

\begin{tabular}{lll} 
Postpartum & Oral iron & IV iron \\
Switzerland & $10<\mathrm{Hb} \leq 11.5 \mathrm{~g} / \mathrm{dL}$ & $\mathrm{Hb} \leq 10 \mathrm{~g} / \mathrm{dL}$ \\
Germany & $8<\mathrm{Hb} \leq 10 \mathrm{~g} / \mathrm{dL}$ & $\mathrm{Hb} \leq 8 \mathrm{~g} / \mathrm{dL}$ \\
\hline Asia-Pacific & $10<\mathrm{Hb} \leq 10.5 \mathrm{~g} / \mathrm{dL}$ & $\mathrm{Hb} \leq 10 \mathrm{~g} / \mathrm{dL}$ \\
NATA & - & $\mathrm{Hb} \leq 10 \mathrm{~g} / \mathrm{dL}$
\end{tabular}

In Germany, the $\mathrm{Hb}$ threshold is $<8 \mathrm{~g} / \mathrm{dL}$, which is below the limit of severe anemia. This value is extremely low and is probably related to economic reimbursement issues(14-18).

Heavy menstrual bleeding is another condition that can require blood transfusion. Although a precise definition of this clinical condition is lacking, according to the National Institute for Health and Care Excellence (NICE) guidelines, it corresponds to a volume of bleeding that causes health problems and social discomfort, roughly $80 \mathrm{~mL}$ per period. Here too, an indication for IV iron therapy can be mentioned because such patients face the risk of transfusion and this process is likely to progress to hysterectomy(43-45).

\section{Recommendations}

- In patients with an $\mathrm{Hb}$ level $\leq 10 \mathrm{~g} / \mathrm{dL}$ who are hemodynamically stable and asymptomatic or mildly symptomatic, oral iron 100-200 mg/ day should continue for up to 3 months, and complete blood count and serum ferritin values should be checked at the end of treatment.

- IV iron therapy should be considered in patients who cannot tolerate or do not respond to oral iron therapy, and have significant symptoms or moderate-severe/severe anemia.

- The physician should start IV iron therapy whenever the Hb value is less than or equal to 9 because this is considered as severe anemia.

- The therapeutic iron dose should be determined on an individual patient basis and should achieve an $\mathrm{Hb}$ level $\geq 11 \mathrm{~g} / \mathrm{dL}$.

$\begin{array}{lll}\text { Postpartum } & \text { Oral iron } & \text { IV iron } \\ \text { Turkey } & 9<\mathrm{Hb} \leq 11 \mathrm{~g} / \mathrm{dL} & \mathrm{Hb} \leq 9 \mathrm{~g} / \mathrm{dL}\end{array}$

\section{Parenteral iron therapy options}

Worldwide, iron deficiency anemia is most commonly treated with oral iron preparations; however, oral preparations are associated with problems such as intolerability, poor patient compliance, insufficient response to treatment, and prolonged treatment. Therefore physicians are increasingly interested in parenteral iron therapy options.

\section{Intramuscular iron therapy}

Some preparations such as iron sorbitex, high-molecular-weight iron dextran, and low-molecular-weight iron dextran can be given intramuscularly (IM). However, IM injections have some significant drawbacks, therefore IM is generally not recommended. Intramuscular injection is painful, has a risk of permanent skin staining, and is associated with the development of sterile abscesses and gluteal sarcomas. Also, intramuscular absorption of iron is slow, the use of iron given via this route is variable, and IM injections are not possible for patients who have reduced muscle mass. IM administration of iron is not safer or less toxic than the IV route, so the most appropriate parenteral route is IV(46-50).

\section{Intravenous iron therapy}

IV iron therapy is not associated with oral and IM iron therapy problems and is a more cost-effective option. IV preparations are more expensive than oral preparations, but the total cost of oral treatment becomes equivalent to IV treatment because repeated administrations are needed in oral treatment. Additionally, the patient has the initiative in oral administration and that makes it difficult to monitor how many doses the patient has actually received; if the patient is not receiving the tablets, the physician prescribes more and more oral preparations to treat the patient so the cost increases and becomes even more than IV treatment. The risk of premature birth, the most serious risk associated with anemia during pregnancy, increases in patients with anemic who are not treated. The cost of care for a premature baby far exceeds that of IV iron treatment, which is why interest in IV iron therapy is gradually increasing(50-53).

\section{High-molecular-weight iron dextran}

Safety concerns that physicians have regarding parenteral iron preparations are related to serious adverse events (anaphylaxis,

Table 1. Conditions during pregnancy that require intravenous iron therapy

Inadequate response to oral iron treatment.

Patient non-compliance with oral iron treatment.

Intolerability of oral iron treatment (gastrointestinal adverse effects).

Presence of severe anemia ( $\mathrm{Hb} \leq 9 \mathrm{~g} / \mathrm{dL})$.

Presence of risk factors (e.g. coagulation disorders, placenta previa). Situations where anemia should be resolved urgently. 
shock, and death) reported in association with high-molecularweight iron dextran, which has been removed from the market in Europe and replaced by newer preparations that have more favorable safety profiles (54-59).

\section{Low-molecular-weight iron dextran}

There are a limited number of studies on the use of low-molecular weight iron dextran during pregnancy and the postpartum period. No serious adverse events have been associated with its use, but mild adverse events have been observed in $5 \%$ of cases. It is contraindicated during the $1^{\text {st }}$ trimester, and the Food and Drug Administration (FDA) pregnancy category is $C$ for the $2^{\text {nd }}$ and $3^{\text {rd }}$ trimesters. Data on its use during the neonatal period is lacking and its effect on lactation is unknown. It can be administered via IV injection or infusion. A test dose is required before each IV administration( $(18,60,61)$.

\section{Ferrous gluconate}

Ferrous gluconate is not available in Turkey. There few studies on its use during pregnancy and there are data concerning its use during the neonatal period. It is contraindicated during the $1^{\text {st }}$ trimester, and its pregnancy category is B for the $2^{\text {nd }}$ and $3^{\text {rd }}$ trimesters. No serious adverse events have been associated with its use. It can only be administered via the IV route. The maximum single dose is $125 \mathrm{mg}$ and a test dose is not required. Its molecular stability is low. Free iron release can occur and may cause liver necrosis $(62,63)$.

\section{Iron polymaltose}

There are a limited number of studies on the use of iron polymaltose during pregnancy and the neonatal period, but no serious adverse events have been reported. Its administration is limited to the IM route(64-67).

\section{Iron sorbitol}

Iron sorbitol is not available in Turkey. There are few studies on its use during pregnancy and no data exists on its use during the neonatal period. It can be administered only via the IM route. No serious adverse events have been reported in association with its use(68).

\section{Iron isomaltoside}

Iron isomaltoside is not available in Turkey. There are a limited number of studies and inadequate data on its use during pregnancy. Studies revealed adverse event in $1 \%$ of patients. The risks associated with its use during lactation are unknown. It can be administered via IV injection and infusion, a test dose is not required(18,61,69-71).

\section{Iron sucrose}

The use of iron sucrose during pregnancy is approved beginning from the $2^{\text {nd }}$ trimester and is FDA pregnancy category B. Numerous studies on its efficacy and safety, as compared with iron dextran and ferrous gluconate, reported that it was well tolerated; with the exception of urticarial, no hypersensitivity reactions were observed (anaphylaxis, angioedema) and no fatal events were observed. On the other hand, the need for erythropoietin decreases, but $\mathrm{Hb}$, iron, transferrin saturation, serum ferritin, and MCV values increase. Moreover, IV therapy provides a higher serum ferritin value and anemia can be controlled more effectively. The use of iron sucrose during pregnancy, the postpartum period, and the neonatal period has been studied extensively; among iron preparations it has the largest data set $(18,40,72-76)$.

\section{Administration of iron sucrose}

Iron sucrose usually comes in the form of a $100 \mathrm{mg} / 5 \mathrm{~mL}$ ampoule. It is administered only via the IV route as a slow injection or infusion. During injection, 1 ampoule should be administered over the course of $\geq 5 \mathrm{~min}$ and the dosage per minute should not exceed $20 \mathrm{mg}$. The maximum dose that can be administered as a single IV injection is $200 \mathrm{mg}$. In adults a test dose of $20 \mathrm{mg} / \mathrm{lmL}$ should first be administered, if an adverse event is not observed within 15 min the remaining dose should be administered in appropriate time. IV infusion is the preferred method of administration, which reduces the risk of hypotension and paravenous injection. For IV infusion, a $100 \mathrm{mg} / 5 \mathrm{~mL}$ ampoule should be diluted with a maximum of $100 \mathrm{~mL}$ of physiologic serum. The administration time should be at least $15 \mathrm{~min}$ for $100 \mathrm{mg}, 30 \mathrm{~min}$ for $200 \mathrm{mg}$, and should not exceed a total dosage of $200 \mathrm{mg} /$ day. Doses exceeding $200 \mathrm{mg} /$ day are not recommended in pregnancy or the postpartum period because there is not enough safety data(77).

\section{Ferric carboxymaltose}

The use of ferric carboxymaltose in pregnant women has been approved from the $2^{\text {nd }}$ trimester. Studies on IV versus oral iron therapies reported that ferric carboxymaltose was associated with a higher rate of patient tolerability, a higher rate of patient compliance, and target value achievement at lower doses, and that was as safe as but more effective than iron sucrose. With ferric carboxymaltose, a high dose of iron can be administered in a single administration in a short time; hence, problems associated with patient compliance and the additional cost of repeated administrations can be avoided. Ferric carboxymaltose has high molecular stability. Labile iron release or liver necrosis has not been observed in association with its use. Data for and experience with ferric carboxymaltose (pregnancy, postpartum period, neonatal period) are gradually increasing(18,78-86).

\section{Administration of ferric carboxymaltose}

A $500 \mathrm{mg} / 10 \mathrm{~mL}$ vial of ferric carboxymaltose is administered only via the IV route.

Criteria for determining the total dose of ferric carboxymaltose:

$\begin{array}{lll}\mathrm{Hb}(\mathrm{g} / \mathrm{dL}) & \text { Patient weight } 35-70 \mathrm{~kg} & \text { Patients weight }>70 \mathrm{~kg} \\ <10 & 1500 \mathrm{mg} & 2000 \mathrm{mg} \\ \geq 10 & 1000 \mathrm{mg} & 1500 \mathrm{mg}\end{array}$

The total dose should not exceed $500 \mathrm{mg}$ in patients who weigh $<35 \mathrm{~kg}$ 
The maximum daily dose is $1000 \mathrm{mg} / 20 \mathrm{~mL}$; because the minimum dose interval is $7 \mathrm{~d}$, this also corresponds to the maximum weekly dose. While administering via injection, the rate of administration should be $100-500 \mathrm{mg} / \mathrm{min}$. Administration time is a minimum of 15 min for doses of 500$1000 \mathrm{mg}$.

Dilution schedule for administering as infusion:

\begin{tabular}{|llll}
\hline Volume & Iron & $\begin{array}{l}\text { Maximum } \\
\text { volume of } \\
\text { physiologic } \\
\text { serum }\end{array}$ & $\begin{array}{l}\text { Minimum } \\
\text { duration of } \\
\text { administration }\end{array}$ \\
\hline $2-4 \mathrm{~mL}$ & $100-200 \mathrm{mg}$ & $50 \mathrm{~mL}$ & - \\
\hline$\geq 4-10 \mathrm{~mL}$ & $\geq 200-500 \mathrm{mg}$ & $100 \mathrm{~mL}$ & $6 \mathrm{~min}$ \\
$\geq 10-20 \mathrm{~mL}$ & $\geq 500-1000 \mathrm{mg}$ & $250 \mathrm{ml}$ & $15 \mathrm{~min}$
\end{tabular}

A placental perfusion study reported that ferric carboxymaltose did not pass to the the fetus via the placenta(87). The FDA approved ferric carboxymaltose in August 2013 and the preparation has since become available as Injectafer; however, to date there has not been a sufficient number of large-scale randomized studies on the use of ferric carboxymaltose during pregnancy and the FDA has specified the pregnancy (2nd and 3rd trimester) category of the drug as $\mathrm{C}$. As such, physicians must carefully consider the risk-benefit ratio when using this drug $(77,88)$.

With regard to international approaches to IV iron therapy, IV iron therapy during pregnancy and the postpartum period in patients with iron deficiency anemia is recommended in the United Kingdom, Germany, Switzerland, Scandinavia, Spain, Eastern Europe, Russia, Pakistan, India, Malaysia, Singapore, Indonesia, China, Thailand, Peru, Argentina, Chile, and Australia. Clear expressions in favor of IV iron are coming from these countries; however, there are many generic drugs on the market, particularly in China, and many studies report that generic iron preparations are less effective and more toxic. Australia strongly recommends IV iron in several indications and is a leading source of publications and guidelines on reducing the need for blood transfusion. Clear expressions about IV iron therapy have not been obtained from the FDA and American College of Obstetricians and Gynecologists (ACOG) from the United States of America(14-18).

\section{Recommendations}

- IV iron therapy should be included in iron deficiency anemia guidelines published by relevant medical organizations in Turkey, and the principles of iron therapy should be clearly described.

\section{Conclusion}

Serious adverse events caused by IV iron preparations that were used in the early years, particularly iron dextran, resulted in concerns about the safety of IV iron therapy. More effective iron preparations have been developed in recent years that are associated with good patient compliance, tolerance, and safety profiles. These preparations are more beneficial than oral iron preparations in some specific indications such as intolerability, low patient compliance, insufficient response to treatment, and prolonged treatment duration. IV iron preparations can be safely used for the treatment of iron deficiency anemia during pregnancy and the postpartum period, particularly for rapid improvement of anemia and rapid replacement of iron storage. Concept: Oluş Api, Christian Breymann, Mustafa Çetiner, Cansun Demir, Tevfik Ecder, Design: Oluş Api, Christian Breymann, Mustafa Çetiner, Cansun Demir, Tevfik Ecder, Data Acquisition or Processing: Oluş Api, Christian Breymann, Mustafa Çetiner, Cansun Demir, Tevfik Ecder, Analysis or Interpretation: Oluş Api, Christian Breymann, Mustafa Çetiner, Cansun Demir, Tevfik Ecder, Literature Search: Figen Yavuz, Writing: Oluş Api, Figen Yavuz, Peer-rewiev: Internal peer-reviewed, Conflict of Interest: C Breymann is a medical advisor of Vifor International/Switzerland in the field of iron deficiency in Obstetrics and Gynecology. O Api, M Çetiner, C Demir, T Ecder, and F Yavuz declare that there are no conflicts of interest, Financial Disclosure: The authors declared that this study has received no financial support.

\section{References}

1. Worldwide prevalence of anaemia. 1993-2005. 2008. http:// whqlibdoc.who.int/publications/2008/ 9789241596657_eng.pdf

2. WHO meeting report. Preconception care to reduce maternal and childhood mortality \& morbidity.2012. http://apps.who.int/iris/ bitstream/10665/78067/1/9789241505000_eng.pdf

3. Beştepe $G$, Bilgin N. Afyon ili 2 ve 4 no'lu sağlık ocaklarındaki gebelerde anemi prevalansı ve anemiyi etkileyen bazı faktörlerin incelenmesi. Sağlık ve Toplum 2002;12:45-53.

4. Mersin S, Kuş C, Yeşildal N, Mayda AS, Şerifi B. Konuralp Kamil Furtun Sağlık Ocağı bölgesi gebelerde anemi araştırması, 8. Ulusal Halk Sağlığı Kongresi Bildiri Kitabı, Diyarbakır 2002;257-60.

5. Oruç O, Tuncer A, Apan E. Adana Yenibaraj Sağlık Ocağı bölgesinde gebelerde anemi prevalansı. 5. Ulusal Halk Sağllğı Kongresi Bildiri Kitabı, İstanbul. 1996;374-8

6. Pekcan G, Karaağaoğlu N. State of nutrition in Turkey. Nutrition and Health 2000;14:41-52.

7. Pirinçci E, Açık Y, Bostancı M, Eren S, Beritanlı H. Elazığ İl Merkezinde Yaşayan Gebelerde Anemi Prevalansı. Fırat Üniversitesi Sağlık Bilimleri Tıp Dergisi 2001;15:449-54.

8. Toksöz P, Ilçin E, Özcan M. Diyarbakır Bağlar Sağlık Ocağı bölgesinde gebe kadınlarda anemi prevalansı. Beslenme ve Diyet Dergisi 1990;19:61-9.

9. Api O, Bayer F, Akıl A, Bektaş M, Api M, Dabak R, Ünal O. İstanbul'da bir eğitim ve araştırma hastanesine başvuran gebelerde anemi prevalansını etkileyen etyolojik ve demografik faktörler. Perinatoloji Dergisi 2009; 17:28-34.

10. Memişoğulları R, Ak Yıldırım H, Uçgun T, Erkan ME, Güneş C, Erbaş M, Güngör A, Yanık ME. Prevalence and etiology of anemias in the adult Turkish population. Turkish Journal of Medical Sciences 2012:42:957-63.

11. Al RA, Unlubilgin E, Kandemir O, Yalvac S, Cakir L, Haberal A. Intravenous versus oral iron for treatment of anemia in pregnancy: a randomized trial. Obstet Gynecol 2005;106:1335-40.

12. Bhandal N, Russell R. Intravenous versus oral iron therapy for postpartum anaemia. BJOG 2006;113:1248. 
13. Khalafallah AA, Dennis AE. Iron deficiency anaemia in pregnancy and postpartum: pathophysiology and effect of oral versus intravenous iron therapy. J Pregnancy 2012; 2012:630519.

14. Bergmann R L, Dudenhausen J W, Ennen J C. et al. Diagnostik und Behandlung der Anämie und des Eisenmangels in der Schwangerschaft und im Wochenbett. Literaturüberblick und Empfehlungen. Geburtsh Frauenheilk 2009;69:682-6.

15. Beris P, Maniatis A. NATA working group on intravenous iron therapy. Guidelines on intravenous iron supplementation in surgery and obstetrics/ gynecology. Transfusion Alternatives in Transfusion Medicine 2007;9:29.

16. Breymann C, Bian XM, Blanco-Capito LR, Chong C, Mahmud G, Rehman R. Expert recommendations for the diagnosis and treatment of iron-deficiency anemia during pregnancy and the postpartum period in the Asia-Pacific region. J Perinat Med 2011;39:113-21.

17. Breymann C, Honegger C, Holzgreve W, Surbek D. Diagnosis and treatment of iron-deficiency anaemia during pregnancy and postpartum. Arch Gynecol Obstet 2010;282:577-80.

18. Sue Pavord, Bethan Myers, Susan Robinson, et al. UK guidelines on the management of iron deficiency in pregnancy. British Journal of Haematology 2012;156:588-600.

19. Breymann C. Iron supplementation during pregnancy. Fetal and Maternal Medicine Review 2002;13:1-29.

20. Reveiz L, Gyte GML, Cuervo LG. Treatments for iron-deficiency anaemia in pregnancy. The Cochrane Library 2007.

21. Savajols E, Burguet A, Grimaldi M, Godoy F, Sagot P, Semama DS. Maternal Haemoglobin and Short-Term Neonatal Outcome in Preterm Neonates. Plos One February 25, 2014.

22. Erez Azulay C, Pariente G, Shoham-Vardi I, Kessous R, Sergienko R, Sheiner E. Maternal anemia during pregnancy and subsequent risk for cardiovascular disease. J Matern Fetal Neonatal Med 2014;29:1-4.

23. American College of Obstetricians and Gynecologists. ACOG practice bulletin no. 95: anemia in pregnancy. Obstet Gynecol 2008;112:201-7.

24. Guyatt GH, Oxman AD, Ali M, Willan A, Mcllroy W, Patterson C. Laboratory diagnosis of iron-deficiency anemia: an overview. J Gen Intern Med 1992; 7:145-53.

25. Hercberg, S.Galan, P.Preziosi, P. Consequences of iron deficiency in pregnant women: Current issues. Clin Drug Invest 2000;19:1-7.

26. No authors listed. Recommendations to prevent and control iron deficiency in the United States. Centers for Disease Control and Prevention. MMWR Recomm Rep 1998;47:1-29.

27. National Institute for Health and Clinical Excellence. Antenatal care: Routine Care for the Healthy Pregnant Woman. Clinical Guideline. London, UK: National Institute for Health and Clinical Excellence; 2008.

28. Bashiri A, Burstein E, Sheiner E, Mazor M. Anemia during pregnancy and treatment with intravenous iron: review of the literature. Eur J Obstet Gynecol Reprod Biol 2003;110:2-7.

29. Khalafallah AA, Dennis AE, Ogden K, Robertson I, Charlton RH, Bellette JM, et al. Three-year follow-up of a randomised clinical trial of intravenous versus oral iron for anaemia in pregnancy. BMJ Open 2012;2.

30. Melamed N, Ben-Haroush A, Kaplan B, Yogev Y. Iron supplementation in pregnancy--does the preparation matter? Arch Gynecol Obstet 2007;276:601-4.

31. Bodnar LM, Cogswell ME, McDonald T. Have we forgotten the significance of postpartum iron deficiency?. Am J Obstet Gynecol 2005;193:36-44.

32. Bruner AB, Joffe A, Duggan AK, Casella JF, Brandt J. Randomised study of cognitive effects of iron supplementation in non-anaemic iron-deficient adolescent girls. Lancet 1996;348:992-6.

33. Murray-Kolb LE. Iron status and neuropsychological consequences in women of reproductive age: what do we know and where are we headed?. The Journal of Nutrition 2011;141:747S-55S.
34. Murray-Kolb LE, Beard JL. Iron treatment normalizes cognitive functioning in young women. The American Journal of Clinical Nutrition 2007;85:778-87.

35. Breymann C, Gliga F, Bejenariu C, Strizhova N. Comparative efficacy and safety of intravenous ferric carboxymaltose in the treatment of postpartum iron deficiency anemia. International Journal of Gynecology and Obstetrics 2008;101:67-73.

36. Froessler B, Cocchiaro C, Saadat-Gilani K, Hodyl N, Dekker G. Intravenous iron sucrose versus oral iron ferrous sulfate for antenatal and postpartum iron deficiency anemia: a randomized trial. J Matern Fetal Neonatal Med 2013;26:654-9.

37. Van Wyck DB, Martens MG, Seid MH, Baker JB, Mangione A. Intravenous ferric carboxymaltose compared with oral iron in the treatment of postpartum anemia: a randomized controlled trial. Obstet Gynecol 2007;110:267-78.

38. Auerbach M, Goodnough LT, Picard D, Maniatis A. The role of intravenous iron in anemia management and transfusion avoidance. Transfusion 2008;48:988

39. Hallak M, Sharon AS, Diukman R, Auslender R, Abramovici H. Supplementing iron intravenously in pregnancy. A way to avoid blood transfusions. J Reprod Med 1997;42:99-103.

40. Peebles G, Fenwick S. Intravenous iron administration in a short-stay hospital setting. Nurs Stand 2008;22:35-41.

41. Seid MH, Derman RJ, Baker JB, Banach W, Goldberg C, Rogers R. Ferric carboxymaltose injection in the treatment of postpartum iron deficiency anemia: a randomized controlled clinical trial. Am J Obstet Gynecol 2008;199:435.el-7.

42. Silverman JA, Barrett J, Callum JL. The appropriateness of red blood cell transfusions in the peripartum patient. Obstet Gynecol 2004;104:1000-4

43. NICE guideline. Heavy menstrual bleeding. 2007. http://www. nice.org.uk/guidance/cg44/resources/guidance-heavy-menstrualbleeding-pdf

44. Van Wyck DB, Mangione A, Morrison J, Hadley PE, Jehle JA, Goodnough LT. Large-dose intravenous ferric carboxymaltose injection for iron deficiency anemia in heavy uterine bleeding: a randomized controlled trial. Transfusion 2009;49:2719-28.

45. Gordon S, Hadley PE, Van Wyck DB, Mangione A. Iron Carboxymaltose, A New Intravenous Iron Agent for Iron Deficiency in Heavy Uterine Bleeding. Obstet Gynecol 2007;109:1-127.

46. Pasricha S, Flecknoe-Brown S, Allen K. Diagnosis and management of iron deficiency anaemia: a clinical update. Med J Aust 2010;193:52532.

47. Solomons NW, Schumann K. Intramuscular administration of iron dextran is inappropriate for treatment of moderate pregnancy anaemia, both in intervention research on underprivileged women and in routine prenatal care provided by public health services. Am J Clin Nutr 2004;79:1-3.

48. Grasso P. Sarcoma after intramuscular iron injection. Br Med J 1973;2:667.

49. Greenberg G. Sarcoma after intramuscular iron injection. Br Med J 1976;1:1508-9.

50. Auerbach M, Ballard H, Glaspy J. Clinical update: intravenous iron for anaemia. Lancet 2007;369:1502-4.

51. Auerbach M, Ballard H. Clinical use of intravenous iron: administration, efficacy, and safety. Hematology Am Soc Hematol Educ Program 2010;2010:338-47.

52. Bhandari S. Beyond efficacy and safety-the need for convenient and cost-effective iron therapy in health care. NDT Plus 2011;4: i14-i19.

53. Szucs TD et al. The costs of iv iron preparations. Haematologica 2009;94:52. 
54. Bailie GR, Clark JA, Lane CE, Lane PL. Hypersensitivity reactions and deaths associated with intravenous iron preparations. Nephrol Dial Transplant 2005;20:1443-9.

55. Chertow GM, Mason PD, Vaage-Nilsen O, Ahlmén J. Update on adverse drug events associated with parenteral iron. Nephrol Dial Transplant 2006;21:378-82.

56. Chertow GM, Winkelmayer WC. On the relative safety of intravenous iron formulations: new answers, new questions. Am J Hematol 2010;85:643-4.

57. Macdougall IC, Bock A, Carrera F, Eckardt KU, Gaillard C, Van Wyck D, et al. The FIND-CKD study-a randomized controlled trial of intravenous iron versus oral iron in non-dialysis chronic kidney disease patients: background and rationale. Nephrol Dial Transplant 2014;29:843-50.

58. Rampton D, Folkersen J, Fishbane S, Hedenus M, Howaldt S, Locatelli F, et al. Hypersensitivity reactions to intravenous iron: guidance for risk minimization and management. Haematologica 2014;99:1671-6.

59. Wysowski DK, Swartz L, Borders-Hemphill BV, Goulding MR, Dormitzer C. Use of parenteral iron products and serious anaphylactic-type reactions. Am J Hematol 2010;85:650-4.

60. Auerbach M, Pappadakis JA, Bahrain H, Auerbach SA, Ballard H, Dahl NV. Safety and efficacy of rapidly administered (one hour) one gram of low molecular weight iron dextran (INFeD) for the treatment of iron deficient anemia. Am J Hematol 2011;86:860-2.

61. Gozzard D. When is high-dose intravenous iron repletion needed? Assessing new treatment options. Drug Des Devel Ther 2011;5:51-60.

62. Faich G, Strobos J. Sodium ferric gluconate complex in sucrose: safer intravenous iron therapy than iron dextrans. Am J Kidney Dis 1999;33:464.

63. Miller HJ, Hu J, Valentine JK, Gable PS. Efficacy and tolerability of intravenous ferric gluconate in the treatment of iron deficiency anemia in patients without kidney disease. Arch Intern Med 2007; 167:1327.

64. Geisser P. Safety and efficacy of iron(III)-hydroxide polymaltose complex/a review of over 25 years experience. Arzneimittelforschung 2007;57:439-52.

65. Ortiz R, Toblli JE, Romero JD, Monterrosa B, Frer C, Macagno E, Breymann C. Efficacy and safety of oral iron(III) polymaltose complex versus ferrous sulfate in pregnant women with irondeficiency anemia: a multicenter, randomized, controlled study. J Matern Fetal Neonatal Med 2011;24:1347-52.

66. Singh K, Fong YF, Kuperan P. A comparison between intravenous iron polymaltose complex (Ferrum Hausmann) and oral ferrous fumarate in the treatment of iron deficiency anaemia in pregnancy. Eur J Haematol 1998;60:119-24.

67. Toblli JE, Brignoli R (2007). Iron(III)-hydroxide polymaltose complex in iron deficiency anemia / review and meta-analysis. Arzneimittelforschung 2007;57:431-8.

68. Wali A, Mushtaq A, Nilofar. Comparative study-efficacy, safety and compliance of intravenous iron sucrose and intramuscular iron sorbitol in iron deficiency anemia of pregnancy. J Pak Med Assoc 2002;52:392-5.

69. Holm C, Thomsen LL, Norgaard A, Langhoff-Roos J. Intravenous iron isomaltoside 1000 administered by high single-dose infusions or standard medical care for the treatment of fatigue in women after postpartum haemorrhage: study protocol for a randomised controlled trial. Trials 2015;16:5.

70. Reinisch W, Staun M, Tandon RK, Altorjay I, Thillainayagam AV, Gratzer $\mathrm{C}$, et al. A randomized, open-label, non-inferiority study of intravenous iron isomaltoside 1,000 (Monofer) compared with oral iron for treatment of anemia in IBD (PROCEED). Am J Gastroenterol 2013;108:1877-88.
71. Wikström B, Bhandari S, Barany P, Kalra PA, Ladefoged S, Wilske J, et al. Iron isomaltoside 1000: a new intravenous iron for treating iron deficiency in chronic kidney disease. J Nephrol 2011;24:589-96.

72. Breymann C. The Use of Iron Sucrose Complex for Anemia in Pregnancy and the Postpartum Period. Seminars in Hematology. 2006; 43:S28-31.

73. Krafft A, Bencaiova G, Breymann C. Selective use of recombinant human erythropoietin in pregnant patients with severe anemia or nonresponsive to iron sucrose alone. Fetal Diagn Ther 2009;25:239-45.

74. Krafft A, Breymann C. Iron sucrose with and without recombinant erythropoietin for the treatment of severe postpartum anemia: a prospective, randomized, open-label study. J Obstet Gynaecol Res 2011;37:119-24

75. Van Wyck DB, Cavallo G, Spinowitz BS, Adhikarla R, Gagnon S, Charytan C, et al. Safety and efficacy of iron sucrose in patients sensitive to iron dextran: North American clinical trial. Am J Kidney Dis 2000;36:88-97.

76. Westad S, Backe B, Salvesen KA, Nakling J. A 12-week randomised study comparing intravenous iron sucrose versus oral ferrous sulphate for treatment of postpartum anemia. Acta Obstet Gynecol Scand 2008;87:916-23.

77. www.eczanet.com/rxmediapharma/

78. Barish CF, Koch T, Butcher A, Morris D, Bregman DB. Safety and Efficacy of Intravenous Ferric Carboxymaltose $(750 \mathrm{mg})$ in the Treatment of Iron Deficiency Anemia: Two Randomized, Controlled Trials. Anemia 2012;2012:172104.

79. Christoph P, Schuller C, Studer H, Irion O, De Tejada BM, Surbek D. Intravenous iron treatment in pregnancy: comparison of high-dose ferric carboxymaltose vs. iron sucrose. J Perinat Med. 2012;40:469-74.

80. Froessler B, Collingwood J, Hodyl NA, Dekker G. Intravenous ferric carboxymaltose for anaemia in Pregnancy. BMC Pregnancy and Childbirth. 2014;14:115.

81. Hussain I, Bhoyroo J, Butcher A, Koch TA, He A, Bregman DB. Direct Comparison of the Safety and Efficacy of Ferric Carboxymaltose versus Iron Dextran in Patients with Iron Deficiency Anemia. Anemia 2013;2013:169107.

82. Kulnigg S, Stoinov S, Simanenkov V, Dudar LV, Karnafel W, Garcia LC, et al. A novel intravenous iron formulation for treatment of anemia in inflammatory bowel disease: the ferric carboxymaltose (FERINJECT) randomized controlled trial. Am J Gastroenterol 2007;102:1-11.

83. Lynseng-Williamson KA,Keating GM. Ferric Carboxymaltose. A review of its use in Iron-deficiency Anemia. Drugs 2009;69:739-56.

84. Moore RA, Gaskell H, Rose P, Allan J. Meta-analysis of efficacy and safety of intravenous ferric carboxymaltose (Ferinject) from clinical trial reports and published trial data. BMC Blood Disorders 2011;11:4.

85. Geisser P. The pharmacology and safety profile of ferric carboxymaltose (Ferinject $\left.{ }^{\circledR}\right)$ : structure/reactivity relationships of iron preparations. Port J Nephrol Hypert 2009;23:11-6.

86. Pfenniger A, Schuller C, Christoph P, Surbek D. Safety and efficacy of highdose intravenous iron carboxymaltose vs. iron sucrose for treatment of postpartum anemia. J Perinat Med 2012;40:397-402.

87. Malek A. In vitro studies of ferric carboxymaltose on placental permeability using the dual perfusion model of human placenta. Arzneimittelforschung. 2010;60:354-61.

88. FDA (US Food and Drug Administration) (2013a) Injectafer (Ferric carboxymaltose) approval letter. (accessed 9 January 2013).http://www.accessdata.fda.gov/drugsatfda_docs/ nda/2013/203565Origls000Approv.pdf 